\title{
PENYELENGGARAAN PENILAIAN HASIL BELAJAR SMK RUJUKAN PROGRAM KEAHLIAN TEKNIK KETENAGALISTRIKAN DI DAERAH ISTIMEWA YOGYAKARTA
}

\author{
Edy Supriyadi ${ }^{1}$ \\ ${ }^{1}$ Jurusan Pendidikan Teknik Elektro, Fakultas Teknik, Universitas Negeri Yogyakarta \\ email : edy_supriyadi@uny.ac.id
}

\begin{abstract}
This study aims to determine the implementation of the assessment of learning achievement on SMK Rujukan at Expertise Program of Electrical Engineering. The data sources of this study were school leaders (school principals, vice principals and heads of departments), teachers, and students on 5 SMK's in Yogyakarta Province. Sample respondents were 8 (Principals/Vice Principals), 39 teachers, and 70 students. The results showed that in general the assessment of students learning achievement on SMK's was fairly good. Based on the analysis of data from the teacher through the questionnaire, in the aspect of Planning Assessment obtained a mean value of 142.17 (72.66\%), and a Standard Deviation of 16.23, fairly good. In the Instrument Development aspect, a mean value of 72.07 (75.07\%) and a Standard Deviation of 6.23 was classified as fairly good. In the aspect of the Implementation of the Assessment, the mean value was 90.51 (68.56\%), and the Standard Deviation was 10.89, which was fairly good. In the aspects of Usage and Reporting of Assessment Results, the average value is $70(70 \%)$, and the Standard Deviation is 8.72, including fairly good. The assessment system of students' learning achievement for SMK Rujukan in Yogyakarta still needs a lot of improvement.
\end{abstract}

Keywords : assessment, vocational high school

\begin{abstract}
ABSTRAK
Penelitian ini bertujuan untuk mengetahui penyelenggaraan penilaian hasil belajar di SMK Rujukan Program Keahlian Teknik Ketenagalistrikan. Sumber data penelitian ini adalah pimpinan sekolah (Kepala sekolah, Wakil, dan Ketua Jurusan), Guru, dan peserta didik di 5 SMK Rujukan di Propinsi Yogyakarta. Sampel responden diambil sebanyak 8 (Kepala Sekolah/Wakil), 39 orang Guru, dan 70 orang Siswa. Hasil penelitian menunjukkan bahwa secara umum sistem penilaian hasil belajar SMK Rujukan di Yogyakarta tergolong Cukup Baik. Berdasarkan analisis data dari Guru melalui kuesioner, pada aspek Perencanaan Penilaian diperoleh nilai Rerata sebesar 142,17 (72,66\%), dan Simpangan Baku sebesar 16,23, tergolong Cukup Baik. Pada aspek Pengembangan Instrumen, diperoleh nilai Rerata sebesar 72,07 (75,07\%), dan Simpangan Baku sebesar 6,23, tergolong Cukup Baik. Pada aspek Pelaksanaan Penilaian diperoleh nilai Rerata sebesar 90,51 (68,56\%), dan Simpangan Baku sebesar 10,89, tergolong Cukup Baik. Pada aspek Pemanfaatan dan Pelaporan Hasil Penilaian, besarnya nilai Rerata sebesar 70 (70\%), dan Simpangan Baku sebesar 8,72, termasuk Cukup Baik. Sebagai Rujukan, sistem penilaian hasil belajar SMK Rujukan di Yogyakarta masih perlu cukup banyak pembenahan.
\end{abstract}

Kata kunci: penilaian, SMK Rujukan

\section{PENDAHULUAN}

Sekolah Menengah Kejuruan (SMK) memiliki peran yang sangat penting dalam memenuhi sumber daya manusia (SDM) berkualitas dan relevan dengan kebutuhan dunia kerja. Lulusan SMK diharapkan mampu berkompetisi baik di tingkat nasional maupun di tingkat internasional. Berkaitan dengan hal tersebut, Kementerian Pendidikan dan Kebudayaan secara berkelanjutan membenahi sistem pendidikan SMK. Salah satu upaya untuk meningkatkan mutu SMK secara lebih sistemik adalah melalui program Sekolah 
Rujukan, atau dikenal dengan istilah SMK Rujukan. Setiap Kabupaten/Kota diharapkan memiliki minimal satu Sekolah Menengah Rujukan/Model (Direktorat Pembinaan SMK, 2016:1).

Tujuan pengembangan SMK Rujukan adalah untuk lebih menjamin keterserapan lulusan pada lapangan kerja yang relevan baik di dalam maupun di luar negeri, atau mampu mengembangkan usaha secara mandiri. Terdapat enam komponen pengembangan SMK Rujukan yaitu: Layanan SMK, Manajemen SMK, Proses Pembelajaran, Sarana Prasarana SMK, Lulusan SMK, dan SMK Sebagai Pusat Belajar. Pada tahun 2017 telah ditetapkan sebanyak 100 SMK yang potensial sebagai SMK Rujukan. Idealnya, SMK Rujukan akan menjadi pusat keunggulan (Centre of excellent) yang akan dijadikan contoh atau model sekolah yang bermutu bagi sekolah-sekolah yang ada di sekitarnya.

Pengembangan sekolah yang sudah ada (existing schools) menjadi SMK Rujukan memiliki beberapa keuntungan dan kelemahan. SMK Rujukan yang saat ini dikembangkan tidak dirancang sejak awal secara khusus sebagai Sekolah Rujukan. Potensi kelemahannya, komponen-komponen pendidikan seperti Guru, tenaga kependidikan, sarana dan prasarana serta komponen lainnya belum terstandar atau tidak dikembangkan secara komprehensif. Potensi keuntungannya, pemerintah tidak memerlukan waktu lama, dan mengeluarkan biaya yang terlalu besar dalam pengembangan SMK Rujukan. Oleh karena itu, perlu dilakukan pengkajian secara komprehensif pada setiap komponen penyelenggaraan pendidikan di SMK Rujukan, meliputi antara lain Guru, sarana prasarana, kurikulum, proses pembelajaran dan penilaian hasil belajar, serta komponen terkait lainnya.

Pembelajaran di SMK Rujukan ditengarai belum efektif, atau setidaknya efektivitas pembelajarannya belum mengimbas ke sekolah-sekolah yang ada di sekitarnya. Hal ini ditunjukkan antara lain oleh hasil belajar yang dicapai. Hasil Ujian Nasional SMK masih relatif rendah, yaitu Rerata 58,42 pada tahun 2016, Rerata 53,63 pada tahun 2017, dan Rerata 45,21 pada tahun 2018 (Pusat Penilaian Pendidikan, 2018).

Terdapat beberapa faktor yang mempengaruhi efektivitas pembelajaran, antara lain kompetensi Guru, pendekatan pembelajaran, fasilitas pembelajaran, dan aktivitas pembelajaran. Penilaian hasil belajar merupakan komponen yang sangat penting, dan sangat mempengaruhi kualitas pembelajaran. Apabila dirancang dan dikembangkan serta dilaksanakan dengan baik, penilaian hasil belajar akan membantu Guru lebih memahami sejauhmana siswa menguasai materi pembelajaran (ETS, 2013:1).

Penilaian dan pembelajaran pada dasarnya merupakan proses kegiatan yang terpadu. Penilaian yang dilakukan secara sistematis, terutama pada penilaian formatif sangat membantu Guru dan Siswa untuk mengetahui sejauhmana tujuan pembelajaran telah dicapai, materi mana yang telah dikuasai, dan materi mana yang belum dikuasai. Hal ini menjadi masukan bagi Guru dalam menyempurnakan kegiatan pembelajaran. Siswa juga akan mengetahui materi apa yang masih perlu dipelajari dan bagaimana mempelajarinya. Berkaitan dengan hal tersebut, perlu dilakukan pengkajian tentang penyelenggaraan penilaian hasil belajar di SMK Rujukan. Penilaian hasil belajar yang dikaji dalam penelitian ini lebih mengarah pada penilaian yang dilakukan Guru atau penilaian kelas, dan penilaian yang diselenggarakan oleh sekolah.

Penilaian merupakan suatu proses untuk mengukur atau menilai kemajuan dan prestasi belajar peserta didik sesuai dengan kriteria kualitas spesifik (IBE UNESCO, 2013:5). Senada dengan pendapat tersebut, Clark (2012:1) mendefinisikan penilaian sebagai suatu proses mengumpulkan dan mengevaluasi informasi tentang apa yang siswa ketahui, dan apa yang dapat dikerjakan agar Guru dapat mengambil keputusan tentang proses 
pembelajaran selanjutnya. Penilaian harus dirancang, dilaksanakan, dan hasilnya dimanfaatkan oleh Guru dan siswa untuk mengoptimalkan efektifitas pembelajaran di kelas. Penilaian terutama ditujukan untuk memberdayakan Guru dan siswa dalam meningkatkan kualitas pembelajaran di kelas. Melalui penilaian kelas yang berkelanjutan, dapat dilakukan pemantauan terhadap kegiatan siswa selama pembelajaran, memperoleh umpan balik mengenai kemajuan belajar siswa, bagaimana siswa belajar, tanggapan siswa terhadap pendekatan pembelajaran yang dilakukan Guru. Umpan balik ini dapat digunakan Guru untuk lebih memusatkan pendekatan pembelajaran yang digunakan, membantu siswa untuk belajar sehingga menguasai seluruh substansi pelajaran sesuai yang direncanakan.

Pembelajaran dan penilaian pada dasarnya saling berkaitan. Keberhasilan setiap kegiatan belajar dapat diukur dari hasil belajarnya melalui penilaian. Tinggi rendahnya hasil belajar siswa melambangkan kualitas proses dan usaha pembelajaran yang telah dilakukan. Penilaian merupakan suatu proses untuk mengetahui sejauhmana pengetahuan, kemampuan atau keterampilan siswa (QAA, 2011:3). Penilaian yang dilakukan oleh guru atau penilaian kelas adalah proses sistematis dalam mengumpulkan, menganalisis dan menginterpretasi informasi untuk menentukan sejauhmana siswa telah mencapai tujuan pembelajaran. Penilaian kelas dirancang dan dilaksanakan oleh masing-masing Guru sesuai mata pelajarannya.

Fungsi penilaian hasil belajar adalah untuk menggambarkan sejauhmana seorang peserta didik telah menguasai suatu kompetensi. Selain itu fungsi penilaian hasil belajar adalah untuk mengevaluasi hasil belajar peserta didik dalam rangka membantu peserta didik memahami dirinya, menemukan kesulitan belajar dan kemungkinan prestasi yang bisa dikembangkan peserta didik serta sebagai alat diagnosis. Penilaian hasil belajar, terutama di
SMK Rujukan hendaknya juga mengarah pada gambaran penguasaan kompetensi peserta didik pada tingkatan internasional. Dengan demikian penilaian diarahkan untuk mendukung mutu pembelajaran guna penguasaan kompetensi setara tingkat internasional.

Menurut Spiller (2015:5), terdapat beberapa hal yang perlu diperhatikan dalam penilaian hasil belajar, antara lain: Peserta didik dilibatkan dalam penilaian, dan perlu ada upaya yang disengaja untuk memastikan pemahaman bersama tentang tugas penilaian, kriteria dan umpan balik. Penilaian harus dirancang untuk mendorong peserta didik untuk mengevaluasi kinerja mereka sendiri. Peserta didik perlu diundang untuk memeriksa dan mengembangkan pandangan dan keyakinan mereka tentang penilaian.

Sesuai dengan Peraturan Menteri Pendidikan dan Kebudayaan Nomor 23 Tahun 2016 tentang Standar Penilaian Pendidikan, penilaian hasil belajar peserta didik pada jenjang pendidikan dasar dan menengah dilaksanakan berdasarkan standar penilaian pendidikan yang berlaku secara nasional. Berdasarkan peraturan tersebut penilaian hasil belajar dilakukan oleh Pendidik, Satuan Pendidikan dan Pemerintah. Penilaian hasil belajar peserta didik pada pendidikan dasar dan pendidikan menengah meliputi aspek sikap, pengetahuan, dan keterampilan. Prosedur penilaian proses belajar dan hasil belajar oleh pendidik dilakukan dengan urutan: menetapkan tujuan penilaian, menyusun kisi-kisi penilaian, mengembangkan instrumen, melakukan analisis kualitas instrumen, melaksanakan penilaian, mengolah, menganalisis, dan menginterpretasikan hasil penilaian, melaporkan dan memanfaatkan hasil penilaian.

Terdapat tiga pendekatan dalam penilaian, yaitu assessment of learning (penilaian akhir pembelajaran), assessment for learning (penilaian untuk pembelajaran), dan assessment as learning (penilaian sebagai pembelajaran). Assessment of learning merupakan penilaian yang dilaksanakan setelah 
proses pembelajaran selesai. Proses pembelajaran selesai tidak selalu terjadi di akhir tahun atau di akhir peserta didik menyelesaikan pendidikan pada jenjang tertentu. Setiap pendidik melakukan penilaian yang dimaksudkan untuk memberikan pengakuan terhadap pencapaian hasil belajar setelah proses pembelajaran selesai, yang berarti pendidik tersebut melakukan assessment of learning. Ujian Nasional, ujian sekolah, dan berbagai bentuk penilaian sumatif merupakan assessment of learning (penilaian hasil belajar). Assessment for learning dilakukan selama proses pembelajaran berlangsungdan biasanya digunakan sebagai dasar untuk melakukan perbaikan proses belajar mengajar. Pada assessment for learning pendidik memberikan umpan balik terhadap proses belajar peserta didik, memantau kemajuan, dan menentukan kemajuan belajarnya. Assessment for learning juga dapat dimanfaatkan oleh pendidik untuk meningkatkan performa peserta didik. Penugasan, presentasi, proyek, termasuk kuis merupakan contoh-contoh bentuk assessment for learning (penilaian untuk proses belajar). Assessment as learning mempunyai fungsi yang mirip dengan assessment for learning, yaitu berfungsi sebagai formatif dan dilaksanakan selama prosespembelajaran berlangsung. Perbedaannya, assessment as learning melibatkan peserta didik secara aktif dalam kegiatan penilaian tersebut. Peserta didik diberi pengalaman untuk belajar menjadi penilai bagi dirinya sendiri. Penilaian diri (self assessment) dan penilaian antar teman merupakan contoh assessment as learning. Dalam assessment as learning peserta didik juga dapat dilibatkan dalam merumuskan prosedur penilaian, kriteria, maupun rubrik/pedoman penilaian sehingga mereka mengetahui dengan pasti apa yang harus dilakukan agar memperoleh capaian belajar yang maksimal.

Sesuai dengan Permendikbud no 23 Tahun 2016 tentang Standar Nasional Penilaian, penilaian oleh pendidik meliputi antara lain: Menginformasikan silabus mata pelajaran pada awal semester, mengembangkan indikator pencapaian KD dan memilih teknik penilaian, mengembangkan instrumen dan pedoman penilaian, melaksanakan penilaian (pengujian), mengolah hasil penilaian, mengembalikan hasil pemeriksaan pekerjaan peserta didik disertai balikan/komentar yang mendidik. Selanjutnya memanfaatkan hasil penilaian untuk perbaikan pembelajaran, dan melaporkan hasil penilaian mata pelajaran pada setiap akhir semester kepada pimpinan satuan pendidikan.

\section{METODE}

Penelitian Survai ini dilakukan untuk mengetahui penyelenggaraan penilaian hasil belajar, yang meliputi perancangan, pengembangan instrumen, pelaksanaan, pemanfaatan, dan pelaporan hasil penilaian di SMK Rujukan bidang keahlian Teknik Elektro di D.I Yogyakarta. Terdapat 14 SMK Rujukan yang menyelenggarakan bidang keahlian Ketenagalistrikan di Propinsi Daerah Istimewa Yogyakarta. Penentuan sejumlah 5 (lima) Sekolah Rujukan sebagai sampel dilakukan secara Cluster-Area Random Sampling. Setiap Kabupaten/Kota diambil satu sekolah secara acak.

Sumber data penelitian ini adalah pimpinan sekolah (Kepala sekolah, Wakil, dan Ketua Jurusan), Guru, dan siswa. Sampel responden diambil sebanyak 8 (Kepala Sekolah/Wakil), 39 orang Guru (Pengajar Kelompok Peminatan), dan 70 orang Siswa. Teknik pengumpulan data dilakukan dengan angket, observasi, analisis dokumen, dan wawancara. Validasi instrumen dilakukan dengan expert judgment. Reliabilitas instrumen diketahui dengan alpha Cronbach. Data yang diperoleh melalui penelitian dianalisis secara deskriptif. Kategori hasil analisis data dapat dilihat pada Tabel 1. 
Tabel 1. Rumus Kategori Hasil Analisis Data

\begin{tabular}{ll}
\hline Interval Nilai & Kategori \\
\hline & \\
$\mathrm{Mi}+1,5 \mathrm{Sbi}<\mathrm{X} \leq \mathrm{Mi}+3,0 \mathrm{SBi}$ & Baik \\
$\mathrm{Mi}<\mathrm{X} \leq \mathrm{Mi}+1,5 \mathrm{SBi}$ & Cukup Baik \\
$\mathrm{Mi}-1,5 \mathrm{Sbi}<\mathrm{X} \leq \mathrm{Mi}$ & Kurang \\
$\mathrm{Mi}-3,0 \mathrm{Sbi}<\mathrm{X} \leq \mathrm{Mi}-1,5 \mathrm{SBi}$ & Sangat Kurang \\
\hline
\end{tabular}

\section{HASIL DAN PEMBAHASAN}

\section{Perencanaan Penilaian}

Data tentang Perencanaan Penilaian diperoleh dari Guru melalui kuesioner yang terdiri atas 46 butir. Hasil analisis data menunjukkan bahwa skor terendah sebesar 119, skor tertinggi sebesar 184, dan rentang nilainya sebesar 65. Berdasarkan hasil analisis diperoleh nilai Rerata (Mean) sebesar 142,17, Simpangan Baku (SB) sebesar 16,23, Modus (Mo) sebesar 138, dan Median (Me) sebesar 138. Kecenderungan kualitas perancangan penilaian dalam penelitian ini didasarkan pada empat kategori. Berikut merupakan kategori tersebut, sekaligus data hasil penelitiannya

Tabel 2. Distribusi Frekuensi Data Perencanaan Penilaian

\begin{tabular}{llll}
\hline Skor & F & Persentase & Kategori \\
\hline $149,5-184$ & 11 & 28,20 & Baik \\
$115-<149,5$ & 28 & 71,80 & Cukup Baik \\
$80,5-<115$ & 0 & 0 & Kurang \\
$46-<80,5$ & 0 & 0 & Sangat Kurang \\
Jumlah & 39 & 100 & \\
\hline
\end{tabular}

Hasil di atas menunjukkan bahwa Guru Rujukan Ketenagalistrikan yang memiliki perancangan penilaian dalam kategori Baik sebanyak 28,20\%, yang termasuk dalam kategori Cukup Baik sebanyak 71,80\%, yang termasuk dalam kategori Kurang sebanyak 0\%, dan yang termasuk dalam kategori Buruk sebanyak 0\%. Berdasarkan nilai Rerata dan tabel distribusi kecenderungan variabel, dapat disimpulkan bahwa perancangan penilaian Guru Rujukan Ketenagalistrikan di SMK tergolong Cukup Baik.

Berdasarkan analisis data hasil observasi, wawancara, dan dokumentasi dapat dikemukakan bahwa sekolah telah menyusun jadwal pembelajaran dan penilaian, meliputi penilaian harian, penilaian tengah semester, dan penilaian kenaikan kelas, ujian sekolah, uji kompetensi, serta Ujian Nasional. Meskipun demikian, rincian dari perencanaan tersebut masih bersifat umum. Perencanaan penilaian hasil belajar yang komprehensif dan sistematis belum sepenuhnya diterapkan di sekolah. Sekolah belum menyusun rancangan penilaian secara komprehensif yang antara lain mencakup: pengembangan tujuan dan hasil pembelajaran yang perlu dilakukan penilaian, jenis penilaian apa saja (penempatan, formatif, diagnostik, sumatif), jadwal pelaksanaan, mekanisme penyelenggaraan, instrumen yang digunakan, pengolahan hasil penilaian, pemanfaatan hasil penilaian, pembiayaan, fasilitas yang diperlukan, dan hal-hal terkait lainnya. Padahal, penilaian yang dirancangan dengan baik, komprehensif dan selaras dengan pembelajaran akan menjadikan pembelajaran lebih efektif, dan peserta didik dapat mencapai hasil belajar secara optimal, serta tidak menyebabkan kecemasan dan stres (Gabrielle, Lynn, dan Ashley, 2017: 7)

Hampir semua Guru telah mengetahui tentang jadwal tersebut dan memahami tugasnya yang berkaitan dengan penilaian hasil belajar. Sebagian besar Guru juga telah mengkoleksi cukup banyak instrumen/ instrumen soal, baik yang dikembangkan sendiri maupun yang berasal dari sumber lain (buku, kegiatan MGMP, soal UN, dll). Setiap Guru telah menyusun rencana penilaian secara terpadu dengan silabus dan rencana pembelajarannya. Di dalam silabus yang telah dikembangkan Guru, telah dijabarkan secara garis besar mengenai teknik dan bentuk penilaian pada setiap Kompetensi Dasar (KD). Meskipun demikian, bentuk dan teknik penilaian dari sebagian besar KD masih bersifat umum, dan belum lengkap. Bentuk dan teknik penilaian sebagian besar cenderung mengarah pada KD yang aspek kompetensinya pada ranah kognitif dan psikomotor. Perencanaan penilaian pada aspek afeksi/sikap belum dirancang secara 
memadai. Di samping itu, contoh butir instrumen yang ada pada silabus juga terkesan seadanya dan belum memenuhi sebagai butir soal yang baik.

Perencanaan penilaian yang dilakukan Guru di Rencana Pelaksanaan Pembelajaran (RPP) relatif lebih baik. Umumnya Guru menyusun RPP pada setiap KD, meskipun dalam satu RPP dapat memuat lebih dari satu pertemuan. Bentuk dan teknik penilaian disusun dengan lebih akurat. Namun demikian, cukup banyak RPP yang belum dilengkapi instrumen/instrumen soal secara lengkap. Lembar observasi untuk tes praktik juga belum memadai. Di samping itu, penilaian yang mengarah pada penguasaan keterampilan berpikir tingkat tinggi (higher order thinking skill) belum dikembangkan dengan baik.

\section{Pengembangan Instrumen}

Data tentang Pengembangan Instrumen Penilaian diperoleh dari Guru melalui kuesioner yang terdiri atas 24 butir. Berdasarkan hasil analisis data diperoleh Skor Terendah sebesar 64,00, Skor Tertinggi sebesar 89,00, dan rentang nilainya sebesar 25,00. Berdasarkan hasil analisis diperoleh harga Rerata sebesar 72,07, Simpangan Baku sebesar 6,23, Modus sebesar 70,00, dan Median sebesar 70,00. Berdasarkan nilai di atas, Pengembangan Instrumen Penilaian secara umum tergolong Cukup Baik.

Tabel 3. Distribusi Frekuensi Data Pengembangan Instrumen

\begin{tabular}{llll}
\hline Skor & F & Persentase & Kategori \\
\hline $78-96$ & 7 & 17,94 & Baik \\
$60-<78$ & 32 & 82,06 & Cukup Baik \\
$42-<60$ & 0 & 0 & Kurang \\
$24-<42$ & 0 & 0 & Sangat Kurang \\
Jumlah & 39 & 100 & \\
\hline
\end{tabular}

Berdasarkan analisis data hasil observasi, wawancara, dan dokumentasi dapat dikemukakan bahwa secara umum, pengembangan instrumen penilaian hasil belajar di SMK Rujukan tergolong Cukup Baik.
Hampir semua instrumen penilaian atau instrumen soal, terutama untuk penilaian harian dan penilaian tengah semester dikembangkan sendiri oleh Guru mata pelajaran. Jenis instrumen soal yang ada di sekolah bervariasi, seperti Tes Tertulis (pilhan ganda dan uraian), dan Tes Unjuk Kerja untuk menguji kompetensi yang berkaitan dengan praktik/psikomotor. Di sekolah belum ada tim khusus yang bertanggungjawab dalam pengembangan instrumen penilaian. Instrumen soal yang mengarah pada keterampilan berpikir tingkat tinggi (higher order thinking skill) juga masih sangat terbatas.

Prosedur pengembangan soal umumnya belum mengacu pada prosedur pengembangan instrumen yang baik. Guru umumnya menyusun butir soal langsung berdasarkan pada indikator pencapaian kompetensi sebagai jabaran dari KD. Guru belum mengembangkan kisi-kisi soal secara memadai, termasuk indikator soal yang dijadikan acuan dalam penyusunan butir soal. Di samping itu, beberapa tahapan dalam pengembangan instrumen soal tidak dilakukan. Misalnya, penelaahan soal dari aspek materi, bahasa, dan konstruk, serta dari analisis daya beda dan tingkat kesulitan butir juga belum dilakukan dengan baik. Materi yang diujikan melalui instrumen penilaian harus sesuai dengan materi pembelajaran dan materi yang ada dalam kurikulum. Apabila tidak sesuai maka tidak dapat mengetahui secara akurat sejauhmana tujuan kurikulum dan pembelajaran telah dicapai.

Keselarasan pembelajaran dan penilaian dapat mengembangkan kemampuan berpikir pemecahan masalah sesuai yang dituntut dalam kurikulum (Ekua T. A. S., 2016:5). Idealnya, pengembangan instrumen soal setidaknya meliputi: Penentuan tujuan tes, Penyusunan kisi-kisi tes, Penulisan soal, Penelaahan soal (review dan revisi soal), Uji coba soal dan analisis, Penyempurnaan, Perakitan soal menjadi instrumen tes. 


\section{Pelaksanaan Penilaian Hasil Belajar}

Data tentang Pelaksanaan Penilaian diperoleh dari Peserta Didik melalui kuesioner yang terdiri atas 33 butir. Berdasarkan hasil analisis data diperoleh nilai terendah 68, tertinggi adalah 121, dan rentang nilainya 54 . Berdasarkan hasil perhitungan diperoleh nilai Rerata sebesar 90,51, Median 89,5, Modus sebesar 80 dan Simpangan Baku sebesar 10,89.

Berdasarkan distribusi frekuensi pada Tabel 4 dapat diketahui bahwa frekuensi tertinggi terdapat pada interval 3 dengan rentang skor 84-91, yaitu sebanyak 21 siswa. Kecenderungan kualitas pelaksanaan penilaian dalam penelitian ini didasarkan pada empat kategori. Berikut merupakan kategori tersebut, sekaligus data hasil penelitiannya. Berdasarkan hasil penelitian diatas, pelaksanaan penilaian secara umum tergolong Cukup Baik.

Tabel 4. Distribusi Frekuensi Data Pelaksanaan Penilaian

\begin{tabular}{llll}
\hline Skor & F & Persentase & Kategori \\
\hline $108-132$ & 5 & 7,15 & Baik \\
$83-<108$ & 48 & 68,57 & Cukup Baik \\
$58-<83$ & 17 & 24,28 & Kurang \\
$33-<58$ & 0 & 0 & Sangat Kurang \\
Jumlah & 70 & 100 & \\
\hline
\end{tabular}

Secara umum, pelaksanaan penilaian hasil belajar di sekolah tergolong Cukup Baik. Penilaian pada penilaian harian, penilaian tengah semester, penilaian akhir semester atau kenaikan kelas, dan ujian akhir sekolah dilaksanakan sesuai rancangan, terutama dari aspek waktunya. Khusus untuk siswa kelas XII dilakukan ujicoba Ujian Nasional, yang instrumen soalnya disusun oleh Dinas Pendidikan Povinsi.

Idealnya, sekolah seharusnya melakukan penilaian yang dilakukan secara sistematis dan berkesinambungan melalui tes awal, formative, diagnostics dan summatif. Sebagian Guru (68\%) melakukan tes awal (pre test) sebelum pelaksanaan pembelajaran, dan tes akhir (post test). Bahkan beberapa Guru menggunakan program aplikasi untuk mengetahui kemajuan belajar siswa dalam pembelajaran. Salah satu aplikasi tersebut adalah Kahoot, yang digunakan dalam melakukan penilaian formatif selama pembelajaran. Penggunaan aplikasi penilaian tidak hanya untuk tujuan akademis, tetapi juga tujuan psikologis. Penilaian melalui program aplikasi tersebut dapat meningkatkan penguasaan terhadap materi pembelajaran, sekaligus meningkatkan kepercayaan diri dengan mengerjakan kuis atau pertanyaanpertanyaan melalui aplikasi tersebut (Khairil, \& Mokshein (2018:659). Hasil penelitian Handoko, Burhanudin T., dan Yetti S. (2019:8) juga menunjukkan bahwa siswa lebih senang mengikuti ujian atau penilaian menggunakan komputer dibanding ujian melalui tertulis.

Penilaian harian dilakukan oleh masingmasing Guru. Meskipun tidak seluruhnya berbarengan sesuai jadwal namun materi yang diujikan sesuai dengan materi yang telah selesai diajarkan. Bentuk tes yang digunakan umumnya sesuai dengan kompetensi yang diujikan. Sebagian instrumen penilaian disusun oleh tim Guru mata pelajaran di sekolah. Sebagian lainnya disusun oleh masing-masing Guru. Dalam pelaksanaannya, Guru langsung mengawasi penilaian harian dengan cukup ketat sehingga sangat jarang terjadi kecurangan.

Penilaian tengah semester umumnya dilakukan serentak sesuai jadwal yang telah disusun. Instrumen soal yang digunakan sebagian besar disusun oleh tim Guru mata pelajaran di sekolah. Guru mata pelajaran yang bersangkutan langsung terlibat dalam pengawasan selama berlangsungnya penilaian tengah semester.

Penilaian akhir semester atau penilaian kenaikan kelas diselenggarakan sesuai jadwal. Instrumen soal disusun oleh tim Guru. Sebagian besar Guru mata pelajaran yang diujikan secara nasional menyusun soal dari instrumen soal UN sehingga kualitas soalnya lebih baik. Hal ini dilakukan sekaligus sebagai penjajagan 
kesiapan/kompetensi siswa dalam menghadapi Ujian Nasional.

Idealnya, teknik penilaian dalam pelaksanaan penilaian menggunakan multi metode meliputi penilaian proses dan produk, antara lain: paper and pencil test, performance test, portfolio, individual oral presentations, quiz, debates, field work reports, mind maps, talk and answer sessions, yang dilakukan baik secara formal maupun informal. Bentuk instrumen yang digunakan disesuaikan dengan metode dan karakteristik kompetensi yang diukur. Instrumen dikembangkan secara sistimatis sesuai dengan prosedur pengembangan instrumen baku. Instrumen harus valid, reliabel, fokus pada kompetensi yang diharapkan, komprehensif, obyektif, berkesinambungan, dan mendidik. Namun demikan, sebagai sekolah Rujukan, hal tersebut belum sepenuhnya bisa dilakukan. Hal ini karena kemampuan Guru dalam bidang penilaian masih kurang baik, dan manajemen sekolah belum memiliki kebijakan khusus terhadap hal tersebut.

\section{Pemanfaatan dan Pelaporan Hasil Penilaian}

Data tentang Pemanfaatan dan Pelaporan Hasil Penelitian diperoleh dari Guru melalui kuesioner yang terdiri atas 25 butir pertanyaan. Berdasarkan hasil analisis data diperoleh nilai terendah sebesar 46 , tertinggi 89 , dan rentang nilainya 43. Berdasarkan hasil perhitungan diperoleh harga Rerata sebesar 70, Median 69 dan Simpangan Baku sebesar 8,72.

Tabel 5. Distribusi Frekuensi Data Pemanfaatan dan Pelaporan Hasil Penilaian

\begin{tabular}{llll}
\hline Skor & F & Persentase & Kategori \\
\hline $82-100$ & 5 & 7,94 & Baik \\
$63-<82$ & 49 & 77,78 & Cukup Baik \\
$44-<63$ & 9 & 14,28 & Kurang \\
$25-<44$ & 0 & 0 & Sangat Kurang \\
Jumlah & 39 & 100 & \\
\hline
\end{tabular}

Sesuai dengan nilai Rerata dan distribusi frekuensi pada tabel di atas, dapat ditegaskan bahwa Pemanfaatan dan Pelaporan Hasil Penilaian tergolong Cukup Baik. Di samping itu, berdasarkan hasil observasi, wawancara, dan dokumentasi, secara umum Pemanfaatan dan Pelaporan Hasil Penilaian di SMK Rujukan tergolong Cukup Baik. Hasil penilaian pada penilaian harian dan penilaian tengah semester digunakan Guru sebagai umpan balik pembelajaran pada KD yang telah diajarkan. Hal ini antara lain digunakan untuk menentukan siswa yang harus ikut remidi, dan siswa yang memperoleh materi pengayaan. Meskipun pelaksanaan remidi juga belum terstruktur dengan baik, namun siswa yang memperoleh hasil kurang baik pada penilaian harian dapat termotivasi untuk belajar lebih giat.

Guru memanfaatkan hasil penilaian untuk membahas kembali materi-materi yang belum dikuasai oleh siswa. Hasil penilaian ini juga dimanfaatkan Guru sebagai bagian penentuan prestasi atau nilai pada Rapor. Khusus untuk pelajaran praktik, Guru umumnya langsung memberikan umpan balik secara lisan ketika perfomansi siswa dalam praktik kurang baik. Bahkan Guru seringkali mendemonstrasikan atau memberikan contoh langsung agar siswa dapat meningkatkan keterampilannya. Hal ini sesuai dengan hasil penelitian Havnes et al (2012:7) yang menunjukkan bahwa umpan balik hasil penilaian, dalam beberapa hal cenderung berbeda antara mata pelajaran teori, misalnya Matematika dan pelajaran praktik pada pendidikan kejuruan. Pada pelajaran praktik, Guru umumnya langsung memberikan umpan balik secara lisan (oral).

Hasil penilaian pada penilaian akhir semester atau penilaian kenaikan kelas digunakan Guru sebagai bagian untuk menentukan nilai pada Rapor dan kenaikan kelas. Di samping itu, hasil tersebut digunakan sebagai umpan balik untuk mengetahui materimateri yang belum dikuasai siswa guna kepentingan pembelajaran berikutnya. Khusus untuk Kelas XII, hasil penilaian akhir semester digunakan juga untuk melihat kesiapan siswa 
dalam menghadapi Ujian Nasional. Hasil Ujian Sekolah digunakan untuk kepentingan penentuan kelulusan siswa.

\section{Penyelenggaraan Penilaian Secara Keseluruhan}

Penyelenggaraan penilaian secara keseluruhan merupakan akumulasi hasil analisis data setiap aspek, yaitu aspek Perencanaan, Pengembangan Instrumen, Pelaksanaan Penilaian, dan Pemanfaatan dan Pelaporan Hasil Penilaian. Hasil analisis penyelenggaraan penilaian secara keseluruhan dapat dilihat pada Tabel 6. Berdasarkan nilai Rerata pada Tabel 6 dapat ditegaskan bahwa Penyelenggaraan Penilaian Hasil Belajar secara keseluruhan di SMK Rujukan tergolong Cukup Baik.

Tabel 6. Hasil Analisis Data Penilaian Secara Keseluruhan

\begin{tabular}{lll}
\hline Aspek & Rerata $(\%)$ & Kategori \\
\hline & & \\
Perencanaan & 72,66 & CukupBaik \\
Pengemb. Instrumen & 72,07 & Cukup Baik \\
Pelaksanaan Pen. & 68,56 & Cukup Baik \\
Pemanfaatan dan Pel. & 70 & Cukup Baik \\
Keseluruhan & 70,82 & Cukup Baik \\
\hline
\end{tabular}

Berdasarkan pemaparan hasil penelitian dapat ditegaskan bahwa secara umum sistem penilaian hasil belajar di SMK Rujukan di Daerah Istimewa Yogyakarta masih tergolong Cukup Baik, namun terdapat cukup banyak yang masih perlu dibenahi. Rancangan penilaian masih bersifat umum dan belum komprehensif, dan belum mengadopsi/ mengadaptasi penilaian terstandar, termasuk tingkat internasional, serta perancangan penilaian belum terkoordinasi, dan belum terkelola dengan baik. Prosedur pengembangan soal kurang memadai, belum mengarah pada pengembangan keterampilan berpikir tinggkat tinggi. Hampir seluruh instrumen berbentuk tes tertulis dan tes praktik. Bentuk non-tes, portofolio, quiz, field work masih sangat terbatas. Keterpaduan penilaian dan pembelajaran relatif belum memadai.
Penilaian hasil belajar pada dasarnya dilakukan sejak penyusunan rencana pembelajaran, selama pelaksanaan pembelajaran, dan setelah pembelajaran. Block (2015:106) menegaskan bahwa guru seharusnya menyelenggarakan penilaian kelas secara komprehensif dan terstandar, yaitu memenuhi keterpaduan dan keselarasan kurikulum, pembelajaran, dan penilaian hasil belajar. Hasil penilaian hendaknya digunakan sebagai umpan balik bagi siswa dan guru dalam meningkatkan kualitas pembelajaran. Hal ini perlu dirancang sejak sebelum pelaksanaan pembelajaran, dan siswa diberi penjelasan tentang tujuan dan manfaat umpan balik serta siswa diminta untuk mendokumentasikan bagaimana mereka menggunakan umpan balik untuk maju ke tahap materi pembelajaran berikutnya (Spiller, 2009:3).

\section{SIMPULAN}

\section{Kesimpulan}

Secara umum, penyelenggaran penilaian hasil belajar SMK Rujukan di Yogyakarta, yang meliputi perancangan, pengembangan instrumen, dan pelaksanaan penilaian, serta pemanfaatan dan pelaporan hasil penilaian tergolong cukup baik. Meskipun demikian, sebagai rujukan, sistem penilaian hasil belajar SMK Rujukan di Yogyakarta masih perlu cukup banyak pembenahan. Hampir di setiap tahapan tersebut, masih terdapat cukup banyak kelemahan/kekurangan.

Kekurangan utama sistem penilaian hasil belajar SMK Rujukan di propinsi Yogyakarta disebabkan sistem penilaian hasil belajar di sekolah belum dikelola secara sistematis, baik terkait kelengkapan komponen maupun sumber daya manusiannya. Hal ini meliputi antara lain: kelengkapan dan kejelasan tujuan dan cakupan materi penilaian, sasaran, pengembangan instrumen penilaian, prosedur dan mekanisme pelaksanaan penilaian, tim pengelola, tugas dan tanggungjawab Guru dalam penilaian, pemanfaatan hasil penilaian, dan sistem informasi penilaian. Belum ada kesamaan 
pemahaman tentang sistem penilaian yang seharusnya dilakukan setiap guru. Pelaksanaan penilaian hasil belajar (penilaian kelas) oleh guru cenderung berbeda sesuai keinginan masing-masing guru. Penilaian yang mengarah pada higher order thinking skill belum dilakukan secara memadai.

$$
\begin{array}{crrr}
\text { Sekolah } & \text { perlu } & \text { melakukan } & \text { penataan } \\
\text { manajemen } & \text { sistem } & \text { penilaian } & \text { secara }
\end{array}
$$$$
\text { komprehensif. Hal ini meliputi antara lain: }
$$
pengembangan tujuan dan cakupan materi penilaian, sasaran, pengembangan instrumen penilaian, prosedur dan mekanisme pelaksanaan penilaian, tim pengelola, tugas dan tanggungjawab Guru dalam penilaian, pemanfaatan hasil penilaian, dan sistem informasi penilaian. Sekolah perlu membentuk tim khusus yang menangani pengelolaan penilaian. Guru perlu meningkatkan kompetensinya dalam bidang penilaian hasil belajar, terutama pada penilaian kelas. Beberapa Guru perlu dilatih secara khusus dalam bidang pengembangan instrumen penilaian baku. Hal ini bisa dilakukan dengan bekerjasama dengan Pusat Penilaian Pendidikan Kementerian Pendidikan dan Kebudayaan atau perguruan tinggi terdekat, serta pihak-pihak terkait lainnya.

\section{DAFTAR RUJUKAN}

Block C. R. 2015. Curriculum, Instruction \& Assessment Equals Evaluation of Student Learning Based on the Classroom Assessment Standards. International Journal of Liberal Arts and Social Science. Vol. 3 No. 4.

Clarke, M. M. 2012. What matters most for student assessment systems: a framework paper. Systems Approach for Better Education Results (SABER) student assessment working paper; no. 1. Washington, DC: World Bank. Diunduh pada 26 September 2019 dari http://documents.worldbank.org/curated/ en/216631468149691772/What-mattersmost-for-student-assessment-systems-aframework-paper
Direktorat Pembinaan SMK. 2016. SMK Rujukan sebagai Pusat SMK Unggulan dan Efektif. Diunduh pada 22 Oktober 2019 dari https://psmk.kemdikbud.go.id/konten/149 6/smk-Rujukan-sebagai-pusat-smkunggulan-dan-efektif

Educational Testing Service. 2003. Linking Classroom Assessment with Student Learning. Diunduh pada 10 September 2019 dari https://www.ets.org/Media/Tests/TOEFL Institutional_Testing_Program/ELLM2 002.pdf

Ekua T.A.S. 2016. Assessment, Student Learning and Classroom Practice: A Review. Journal of Education and Practice. ISSN 2222-1735 (Paper) ISSN 2222-288X (Online) Vol.7, No.21.

Handoko, Burhannudin T, \& Yetti S. 2019. The Evaluation Of Computer-Based National Examination System In Indonesia. Indonesian Journal of Educational Review.Vol. 6, No.1, P 35-43

Havnes A, Smith K, Dysthe O, \& Ludvigsen K. 2012. Formative assessment and feedback: Making learning visible Studies in Educational Evaluation. Studies in Educational Evaluation. 38 (2012) 21-27

Khairil, L. F., \& Mokshein, S. E. (2018). 21st Century Assessment: Online Assessment. International Journal of Academic Research in Business and Social Sciences, 8(1), 659-672.

Lindstrom, Gabrielle, Taylor, Lynn, Weleschuk \& Ashley. 2017. Guiding Principles for Assessment of Student Learning. Taylor Institute for Teaching and Learning Guide Series. Calgary, AB: Taylor Institute for Teaching and Learning at the University of Calgary. Diunduh 16 Oktober 2019 dari https://www.ucalgary.ca/taylorinstitute/g uides

Menteri Pendidikan dan Kebudayaan. 2016. Peraturan Menteri Pendidikan dan 
Kebdayaan no 23 Tahun 2016 tentang Standar Nasional Penilaian.

Pusat Penilaian Pendidikan, 2018. Laporan hasil ujian nasional. Diunduh pada 20 Oktober 2019 dari https://hasilun.puspendik.kemdikbud.go.i d/\#2016-2017-

2018!smp!capaian nasional!99\&99\&999 !T\&T\&T\&T\&1\&!1!\&

Rahmana A, Muhamad H. N, Ibrahim M. M., \& Ahmad J. 2013. Assessment Practices for Competency Based Education and Training in Vocational College, Malaysia. International Conference on Education \& Educational Psychology 2013 (ICEEPSY 2013). Procedia - Social and Behavioral Sciences 112 (2014) $1070-1076$

Spiller D. 2009. Assessment: Feedback to promote student learning. Waikato: Teaching Development.

The Quality Assurance Agency. 2011. Understanding assessment: its role in safeguardingacademic standards and quality in higher education. Diunduh pada 23 Oktober 2019 dari https://dera.ioe.ac.uk/12286/7/Understan dingAssessment_Redacted.pdf 